\title{
Inpatient Readmission Insidence of National Health Insurance Patients at Partner Hospitals of BPJS- Health in Sukabumi 2015
}

\author{
* Atmiroseva, ** Atik Nurwahyuni \\ * Faculty of Public Health Universitas Indonesia \\ ** Department Health Administration and Policy, Faculty of Public Health Universitas Indonesia
}

Email: rosevaatmi@gmail.com

\begin{abstract}
The INA-CBG payment system in the JKN program allegedly increasing the incidence of readmission. This study aims to map the incidence of readmission in JKN participants admitted to thirteen partner hospitals of BPJS-Health in Sukabumi. The research design is a descriptive study with the unit of analysis is patient. The study used secondary data from inpatient claims in thirteen partner hospitals BPJS-Health Sukabumi which has been verified during 2015. The study found that the number of readmission is $8.81 \%$ with the most readmission incidence occurs in the equal CMG category and at the least in the equal severity level category. The cost of inpatient readmission services is more expensive 104-113\% of the initial care cost. Moreover, about 15$16 \%$ cases of severity level readmission is increasing and $12-13 \%$ of its severity level is decreased. Less than $3 \%$ cases of readmission ended not good because they died, were referred, or had to come home forcibly.
\end{abstract}

Keywords: Adherence level, Prolanis' participant, type 2 diabetes, determinants.

Abstrak. Sistem pembayaran INA-CBG pada program JKN diduga meningkatkan kejadian readmisi. Penelitian ini bertujuan untuk memetakan kejadian readmisi pasien JKN yang dirawat inap di tiga belas rumah sakit mitra kerja BPJS Kesehatan Cabang Sukabumi. Desain penelitian adalah studi deskriptif dengan unit analisis adalah pasien. Penelitian menggunakan data sekunder dari klaim rawat inap dari tiga belas rumah sakit mitra kerja BPJS Kesehatan Cabang Sukabumi yang sudah terverifikasi selama tahun 2015. Penelitian menemukan angka readmisi sebesar $8.81 \%$ dengan kejadian readmisi terbanyak terjadi pada kategori readmisi dengan CMG sama dan paling sedikit pada kategori readmisi dengan severity-level sama. Biaya pelayanan readmisi rawat inap lebih mahal 104-113 persen dari biaya rawatan awal dan sekitar 15-16\% kasus readmisi severity level-nya naik dan 12-13\% severity level-nya turun. Kurang dari 3\% kasus readmisi berakhir tidak baik karena meninggal, dirujuk, atau minta pulang paksa.

Kata kunci: Readmisi, JKN, INA-CBG

\section{INTRODUCTION}

The Social Security Administering Body (BPJS) of Health as the organizer of the National Health Insurance $(\mathrm{JKN})$ program pays the hospitalization fee for JKN patients in hospitals. The payment is made with a diseasebased payment model which has the same symptoms/characteristics, the same resource usage, service/actions and associated with a financing group known as Indonesia Case Based Group or INA-CBG. The implementation of INA-CBG requires hospitals to exercise the quality control and cost control to be more efficient without reducing the quality of service.

The negative impact of the INA-CBG payment system implementation is the potential of fraud in the form of upcoding, unbundling, and sub-standard service delivery, including inpatient hospital admissions to deal with small-scale INA-CBG tariffs. The limited understanding of hospital management and medical personnel on the casemix system and the weak regulations on readmission would further increase the potential for patient readmission of JKN participants.

Unnecessary readmission is one form of hospital response in addressing the change of payment pattern from fee for service to Diagnosis Related Groups (DRGs) system, in Indonesia called INA-CBG. It is generally evident that DRGs-based payments in the United States have significantly lowered Average Length of Stays (ALOS) as well as the rate of hospital admissions. (Feinglass \& Holloway, 1991 in Or \& Häkkinen, 2011). Another study found that prospective payment system has different contradictory effects depending on the magnitude of DRGs payment incentives. These were found in hospitals in New York that the length of hospitalization days decreased on non-procedural HIV patients who were paid lower. Meanwhile, the hospitalization rate rises on HIV patients with the higher paid from the same case before the tariff changed. (Gilman, 2000 in Or \& Häkkinen, 2011).

DRGs payment systems might negatively affect service quality. Studies in the United Kingdom suggest that the impact of prospective payment depends on the efficiency of the hospital before the prospective payment pattern is applied (Cutler, 1995 in Or \& Häkkinen, 2011). The study also found an increasing number of readmission cases in the prospective payment systems without any apparent change in morbidity Another study found that there was a 
negative effect on short-term health outcomes after treatment for Acute Myocard Infarction due to cost control in the prospective payment system, although it did not affect patient survival for more than one year after treatment. (Shen, 2003 in Or \& Häkkinen, 2011).

In several studies conducted in European countries which apply DRGs payments, in Italy there is a $17 \%$ reduction in hospital stay, with daily hospital access was increasing sevenfold. On the other hand, the average length of hospital day also decreased by $21 \%$. While the morbidity rate increases without significant changes in mortality as well as the readmission rates. (Louis and Colleagues, 1999 in Or \& Häkkinen, 2011). In the UK, ALOS decreased significantly when Payment by Results (PbR) was conducted. However, there has been a change in the quality of care in the form of hospitalization, death within 30 days post-operative, and emergency readmission after fracture treatment. The Audit Commission in 2008 has stated that there is no significant influence of $\mathrm{PbR}$ on DRG-based hospital payments. (Farrar et al., 2009 in Or \& Häkkinen, 2011).

In Indonesia, a study by Hidayat et al. (2015) stated that the total cost of INA-CBG claims for inpatient services from January 2014 to July 2015 and the period of February 2014 to August 2015 is IDR 42.4 trillion. The incident of readmission contributed IDR 4.17 trillion, of which IDR 1.86 trillion was a suspected case of problematic readmission. If a $9 \%$ readmission rate does not occur, the INA-CBG hospitalization fee only requires IDR 38.21 trillion. Comparing this cost to the difference between BPJS-Health revenues as of 31 December 2014 amounting to IDR 40.72 trillion with BPJS-Health expenditure reaching IDR 42.65 trillion (CNN Indonesia, 2015), this means that there is a deficit of Rp 1.93 trillion. If the cost of readmission could be saved, then the cost incurred by the JKN program would be much reduced. Recommendations for reducing inpatient readmission, include improving INA-CBG design to reduce negative implications as a measure to reduce preventable readmission. Interventions to reduce the rate of readmission should be aimed at various dimensions, including improvement of quality and safety of care where the government should invest to improve the quality of hospital services. (Hidayat et al., 2015).

Readmission is a concerning event in many countries in the world, which apply prospective payments to DRG systems, including in Indonesia with INA-CBG. Readmission is undesirable and a disadvantage of the DRG system which increases the unnecessary cost of health services and lowers the quality of health services obtained by insurance participants in countries implementing DRG systems. In Indonesia, the number of INA-CBG payments is very significant. However, unlike other countries which have long been implementing DRG system, Indonesia still has no regulation or application which could assist the implementation of sanctions for hospitals who do readmission as a form of response to payment with the INA- CBG package system.
The General Audit Report in Ontario, Canada stated that the absence of standard procedures for communicating discharge information with subsequent care providers, including primary care, home care or long-term care, has been a striking disadvantage in a health system causing thousands of unnecessary readmissions to the hospital (Osla, 2014). Readmission causes a decline in the quality of health services obtained by JKN participants and increases the greater cost than it should be. However, the study of readmission in Indonesia has not been found. Therefore, this study aims to map the incidence of JKN hospitalized patient readmission at thirteen partner hospitals of BPJS-Health Sukabumi during 2015.

\section{METHODS}

The research design is a descriptive study. The analytical unit is an advanced inpatient case at 13 partner hospitals of BPJS Health Sukabumi during 2015. In this study, the incidence of readmission is defined as hospitalization more than once in less than 30 days after the discharge of care, which previously stated healed and treated at the same hospital under the same conditions. The case of readmission is divided into four categories: (1) equal Case Mixed Group (CMG), (2) equal Adjacent Diagnosis Related Groups (DRG), (3) equal Severity Level, and (4) equal Primary Diagnosis. In a readmission period of less than 30 days from the date of initial admission, only one case of readmission was investigated.

\section{RESULTS AND DISCUSSIONS}

Table 1. Number of Cases, ALOS, and Inpatient Costs of JKN Patients at Partner Hospitals of BPJS-Health in Sukabumi 2015

\begin{tabular}{ccccccc}
\hline $\begin{array}{c}\text { Hospital } \\
\text { name }\end{array}$ & $\begin{array}{c}\text { Hospital } \\
\text { type }\end{array}$ & $\begin{array}{c}\text { Number } \\
\text { of cases }\end{array}$ & $\begin{array}{c}\text { ALOS } \\
\text { (days) }\end{array}$ & $\begin{array}{c}\text { Total } \\
\text { hospital } \\
\text { cost } \\
\text { (Million }\end{array}$ & $\begin{array}{c}\text { Total INA- } \\
\text { CBGs } \\
\text { payment } \\
\text { (Million }\end{array}$ & $\begin{array}{c}\text { Total } \\
\text { hospital } \\
\text { cost }- \text { total } \\
\text { INA-CBGs } \\
\text { payment } \\
\text { (Million }\end{array}$ \\
& & & & IDR) & IDR) & $\begin{array}{c}\text { IDR) } \\
\text { (n) }\end{array}$ \\
& & & & &
\end{tabular}

City of Sukabumi

$\begin{array}{lcccccc}\begin{array}{l}\text { Public } \\ \text { hospital 1 }\end{array} & \text { B } & 14,975 & 5.51 & 62,972 & 68,427 & 5,455 \\ \begin{array}{l}\text { Public } \\ \text { hospital 2 }\end{array} & \text { D } & 4,699 & 3.34 & 10,672 & 13,524 & 2,851 \\ \begin{array}{l}\text { Private } \\ \text { hospital 1 }\end{array} & \text { D } & 11 & 7.82 & 325 & 54 & (271) \\ \begin{array}{l}\text { Private } \\ \text { hospital 2 }\end{array} & \text { D } & 13 & 2.54 & 61 & 50 & (11) \\ \begin{array}{l}\text { District of Sukabumi } \\ \begin{array}{l}\text { Public } \\ \text { hospital 3 }\end{array}\end{array} & \text { C } & 2,992 & 4.22 & 10,381 & 11,114 & 763 \\ \begin{array}{l}\text { Public } \\ \text { hospital 4 }\end{array} & \text { C } & 8,019 & 4.98 & 26,501 & 29,174 & 2,672 \\ \begin{array}{l}\text { Private } \\ \text { hospital 3 }\end{array} & \text { D } & 2,177 & 4.24 & 8,230 & 8,440 & 209 \\ \begin{array}{l}\text { Public } \\ \text { hospital 5 }\end{array} & \text { C } & 5,365 & 4.02 & 14,418 & 16,570 & 2,151\end{array}$




\begin{tabular}{|c|c|c|c|c|c|c|}
\hline $\begin{array}{l}\text { Private } \\
\text { hospital } 4\end{array}$ & D & 203 & 4.15 & 697 & 763 & 66 \\
\hline $\begin{array}{l}\text { Private } \\
\text { hospital } 5\end{array}$ & D & 1,281 & 3.56 & 6,177 & 5,242 & (935) \\
\hline $\begin{array}{l}\text { Private } \\
\text { hospital } 6\end{array}$ & $\mathrm{C}$ & 1,091 & 3.97 & 6,805 & 4,699 & $(2,105)$ \\
\hline \multicolumn{7}{|c|}{ District of Cianjur } \\
\hline $\begin{array}{l}\text { Public } \\
\text { hospital } 6\end{array}$ & B & 12,859 & 4.87 & 52,359 & 54,138 & 1,779 \\
\hline $\begin{array}{l}\text { Public } \\
\text { hospital } 7\end{array}$ & $\mathrm{D}$ & 1,811 & 3.86 & 3,063 & 5,053 & 1,990 \\
\hline Total & & 55,496 & 4.71 & 202,667 & 217,284 & 14,616 \\
\hline
\end{tabular}

Serving JKN participants in Sukabumi City, Sukabumi District, and Cianjur District, BPJS-Health Sukabumi makes cooperation with 13 public and private hospitals. During 2015, there were 55,496 inpatients with total hospital costs of IDR 202.7 billion and INA-CBG payments of IDR 217.3 billion. With that being said, there was a difference in the payment of INA-CBG by IDR 14.6 billion (Table 1).

\begin{tabular}{lcc}
$\begin{array}{l}\text { Table 2. Number of JKN Inpatients Readmission according to Readmission Categories at } \\
\text { Partner Hospitals of BPJS-Health in Sukabumi 2015 }\end{array}$ \\
\hline \multicolumn{1}{|c}{ Readmission category } & Number of cases & Readmission rate \\
\hline Equal CMG & 1,806 & $3.37 \%$ \\
Equal Adjacent DRG & 1,172 & $2.16 \%$ \\
Equal severity level & 857 & $1.57 \%$ \\
Equal primary diagnose & 933 & $1.71 \%$ \\
Total & 4,768 & $8,81 \%$ \\
\hline
\end{tabular}

Table 2 shows the number of inpatient care readmission of JKN patients at 13 partner hospitals of BPJS-Health Sukabumi (2015) reached $8.81 \%$. The order of readmission numbers from the smallest to the largest is based on the equal Severity Level $1.57 \%$, equal Primary Diagnosis $1.71 \%$, equal Adjacent DRG $2.16 \%$ and equal $\mathrm{CMG}$ $3.37 \%$. This readmssion rate is lower than the result of Hidayat's research (2015) which found the case of readmission of $9.76 \%$ where $4.4 \%$ of them are classified as problematic. The percentage of readmission cases in Hidayat's study (2015) was based on the equal INA-CBG, which in this study is similar to the readmission category with equal Severity Level as the readmission number is $1.57 \%$. However, as Hidayat's study (2015) which also limits the readmission to the same hospital, the real-time number might be greater if they include intermittent readmission. Similarly, when compared with the results of the study by Hines et al. (2014), found an incidence of readmission in the United States for all causes of $13.8 \%$ in all types of hospital payments.

Another study by Donze et al. (2013) found that there were $22.3 \%$ of readmission cases within 30 days with a preventable readmission rate of $8.5 \%$. When compared with the largest readmission rate in this study, which is the category of readmission with an equal CMG 3.37\%, this number is smaller than the results of the study Donze et al. (2013). This happened because only the D561 (Beta Thalassemia) and N189 (Chronic Renal Failure) diagnosis are excluded as unpreventable readmissions in this study.

In general, the purpose of measuring the readmission rate is to generate the background information needed to manage readmission. Non-financial incentive is publication or public reporting regarding readmission rates; for example, showing the relative performance of a hospital to other hospitals. This, in theory, decreases the readmission through two interconnected paths. The first is the selection pathway, in which the patient chooses a hospital with a lower readmission (demand reaction). While, the second is the change pathway, in which the hospital reduces the readmission because they find that their hospital is not performing feasibly (Kristensen et al., 2015). From this study, BPJS-Health could obtain the readmission data of partner hospitals which could be useful for the hospital credensialing study and provide feedback to the hospital in order to reduce the rate of readmission. If the hospital's readmission number is published, then JKN participants could choose the inpatient service which is more in line with the expected standard.

From the 13 partner hospitals of BPJS-Health Sukabumi in 2015, there are two hospitals which there is no case of readmission, namely Private Hospital-1 and Private Hospital-2. Both hospitals are located in the city of Sukabumi and as new hospitals in cooperation. Two other private hospitals only serve the emergency hospitalization with relatively few cases, so it could not be declared as a hospital which free from readmission.

Inpatient admission costs consist of two components: initial admission and subsequent admission. Description of the readmission cost separated independently with the assumption that these cases should not need to occur if the initial care is done optimally, so it does not require continued care. The consequence of the INA-CBG payment for the follow-up care is the potential cost which could be saved by BPJS-Health in the implementation of JKN program.

Table 3 shows the total payment of INA-CBG fees for the initial care and subsequent care. It appears that in all four categories of readmission the total cost of follow-up care is greater than the total initial care cost. In the last column, it shows that the total cost of follow-up care for the equal severity level readmission category reached $104 \%$ of the initial care. Whilst for the CMG category, the total cost of follow-up care reached $113 \%$ of the initial care. This occurrence is not only a disadvantage in terms of the burden of costs to be burdened by BPJS-Health, but also affect the number of availabile beds (supply-side) for hospitalization of JKN patients in the hospital. 
Table 3. INA-CBG Cost Comparison between Initial Cases and Subsequent Cases of JKN Inpatient Participants at Partner Hospital of BPJS-Health Sukabumi 2015

\begin{tabular}{lcccc}
\hline $\begin{array}{c}\text { Readmission } \\
\text { category }\end{array}$ & $\begin{array}{c}\text { Number } \\
\text { of cases }\end{array}$ & $\begin{array}{c}\text { INA-CBS } \\
\text { payment for } \\
\text { nitial admission } \\
\text { (Million IDR) }\end{array}$ & $\begin{array}{c}\text { INA-CBS } \\
\text { payment for } \\
\text { readmission } \\
\text { (Million IDR) }\end{array}$ & $\begin{array}{c}\text { \% cost of } \\
\text { redmission/initial } \\
\text { admission }\end{array}$ \\
\hline Equal CMG & 1,806 & 7,553 & 8,508 & $113 \%$ \\
$\begin{array}{l}\text { Equal Adjacent } \\
\text { DRG }\end{array}$ & 1,172 & 4,777 & 5,134 & $107 \%$ \\
$\begin{array}{l}\text { Equal severity } \\
\text { level }\end{array}$ & 857 & 3,329 & 3,476 & $104 \%$ \\
$\begin{array}{l}\text { Equal primary } \\
\text { diagnose }\end{array}$ & 933 & 3,752 & & $107 \%$ \\
\hline
\end{tabular}

The case of readmission is not only detrimental in terms of financing, but also the impact on the output quality of health services received by JKN participants in the disease treatment. BPJS-Health needs to analyze and look for potential fraud as early as possible in order to strengthen anti-fraud function and in the context of controlling the health services quality in JKN program.

The output of readmission case could be seen from 2 things, which are number of death and increasing of disease severity level from initial admission case. In the Table 4, we could see the proportional picture of how to get discharged from hospitals on the follow-up care in the four categories of readmission studied. It is seen that the way "healed" discharged patients reached more than $97 \%$ in all categories of readmission. However, attention should be drawned to the readmission case patient who goes home "dead", ranging from $0.93 \%$ in the case of readmission with the equal severity level and up to $1.76 \%$ in the case of readmission with the equal primary diagnosis. Similarly, with the way of discharged from the hospital as "referred" and "forced discharged". Total number of inadequate discharged way in readmission cases are amounted to less than $3 \%$.

\begin{tabular}{lcccc}
\multicolumn{4}{c}{$\begin{array}{c}\text { Table 4. Proportion of Cases by Category of Readmission and How to Get Discharged of } \\
\text { Inpatient JKN Participants at Partner Hospital BPJS-Health Sukabumi 2015 }\end{array}$} \\
$\begin{array}{l}\text { Readmission } \\
\text { category }\end{array}$ & Healed & $\begin{array}{c}\text { Referred to } \\
\text { advanced-level } \\
\text { hospitals }\end{array}$ & $\begin{array}{c}\text { Forcedly } \\
\text { discharged from } \\
\text { hospital }\end{array}$ & Dead \\
\hline Equal CMG & 97.45 & 0.66 & 0.55 & 1.33 \\
$\begin{array}{l}\text { Equal Adjacent } \\
\text { DRG }\end{array}$ & 97.27 & 0.51 & 0.60 & 1.62 \\
$\begin{array}{l}\text { Equal severity } \\
\text { level }\end{array}$ & 98.13 & 0.47 & 0.47 & 0.93 \\
$\begin{array}{l}\text { Equal primary } \\
\text { diagnose }\end{array}$ & 97.18 & 0.47 & 0.59 & 1.76 \\
\hline
\end{tabular}

The RAND Corporation study found that prospective payment systems (DRGs) led to a $20 \%$ increase in the trend of patients being discharged from hospitals in unstable conditions. However, mortality within 30-180 days after hospitalization was not affected (Rogers et al., 1990 in Or \& Häkkinen, 2011). In addition, after the implementation of the prospective payment system, ALOS decreased significantly, with no significant impact on readmission rates and patients were diagnosed more severely at admission (Keeler et al., 1990: Kahn et al., 1991 in Or \& Häkkinen, 2011). The results of this study are not sufficient to state whether the number of deaths increased or not because it must be compared with the data before the implementation of INA-CBG payment system. The results of this study could only state that in the case of JKN patient readmission, less than 3\% ends home in poor condition due to death, referral, or forced discharged, usually due to patient dissatisfaction with hospital services.

Table 5. Severity Subsequent of Advanced Treatment Compared with Initial Treatment According to Readmission Category of JKN Participants at Partner Hospital of BPJS-Health Sukabumi 2015

\begin{tabular}{lccc}
\hline Readmission category & Decreasing & Equal & Increasing \\
\hline Equal CMG & $13.46 \%$ & $70.21 \%$ & $16.33 \%$ \\
Equal Adjacent DRG & $11.95 \%$ & $71.76 \%$ & $16.30 \%$ \\
Equal primary diagnose & $11.90 \%$ & $72.99 \%$ & $15.11 \%$ \\
\hline
\end{tabular}

Table 5 shows that the largest proportion of inpatient admissions in JKN patients has the same level of $70-73 \%$ of total readmission cases. There are approximately 15$16 \%$ and $12-13 \%$ of readmission cases in the three categories of readmission with increasing and decreasing level. However, we have not been able to draw certain conclusions from the obtained data. It could only be stated that $15-16 \%$ of readmission cases increase in severity level or worsen the disease. This figure is far greater than the output of inpatient readmission case which ends with death. The existence of this information is expected to encourage further research by the Ministry of Health and BPJS-Health related to the impact of readmission on the quality of inpatient services for JKN participants.

\section{CONCLUSIONS}

The rate of inpatient admissions of JKN participants at the partner hospitals of BPJS Health Sukabumi during 2015 is $8.81 \%$, lower than the national rate and compared with other countries. The cost of readmission services is more expensive than the initial treatment cost. The cost of readmission reaches a range of $104-113 \%$ of the initial care cost. In the three categories of readmission, about $15-16 \%$ increased level and 12-13\% decreased its level.

The results of this study could only state that in the case of JKN patient readmission, less than $3 \%$ ends home in bad conditions due to death, referral, or forced discharged, usually due to patient dissatisfaction with hospital services. It is necessary to examine and establish the definition of readmission which would be used in the quality management standard of JKN patients in hospitals. Moreover, it is also useful for further study in formulation of the readmission regulation. The rules would be used specially related to the readmission cases which could be prevented or there is potential fraud or moral hazard. BPJSHealth needs to conduct a more detailed study on the behavior of inpatient readmission in JKN participants at the 
hospital, so there could be done real steps of establishing anti-fraud application and recredensialing criteria.

This study recommends the use of readmission categories which are alligned to the type of disease. These categories would further develop its readmission provisions, with regard to hospital behavior patterns. As an example, for the case of care which allows the hospital to perform nonprocedural treatmen, this should not use the category of the same DRG Adjacent Readmission. In contrast, for infectious diseases, it is recommended that the use of the same DRG Adjacent Readmission category be able to monitor the repeated pattern of similar cases of fever diagnosed as Typhoid and DHF in the two readmission treatments.

It is necessary to set the time period for hospital wide readmission as it would affect the number of readmission cases or readmission rate obtained. Indonesia needs to develop a special study on the determination of priority diagnosis related to the readmission regulation. This also shoud consider the characteristics of the primary diagnosis which many cases of readmission cases in each country is vary one and another. For detected diagnoses which have high frequency of readmission and high cost, BPJS-Health needs to create an Anti-Fraud Application that could detect the incidence of readmission cases under these conditions.

\section{REFERENCES}

CNN Indonesia,

www.cnnindonesia.com/nasional/20150505201700-20

51412/laporan-keuangan-bpjs-kesehatan-wajar-tanpa-pengecualian/; diakses pada 31 Mei 2016

Donze, Jacques; Aujesky, Drahomir; Williams, Deborah; Schnipper, Jeffrey L. (2013). Potentially avoidable 30-day hospital readmissions in medical patients: derivation and validation of a prediction model. Dalam https://www.ncbi.nlm.nih.gov/pubmed/23529115, diakses pada 24 April 2017

Hidayat B, Pujiyanto, Nurwahyuni A, dan Hidayat T. Caveat INA CBG Readmisi, Bloody Discharge dan uppier Induced Demand: Analisis Data Klaim INA CBG Periode Januari 2014 s.d Juli 2015.

Hines, Anika L.; Barret, Marguerite L.; Jiang, H. Joanna; and Steiner, Claudia A. (2014). Conditions With the Largest Number of Adult Hospital Readmissions by Payer, 2011. Dalam https://www.hcupus.ahrq.gov/reports/statbriefs/sb172-Conditions-ReadmissionsPayer.jsp, diakses pada 19 April 2017.

Kristensen, Søren Rud; Bech, Mickael; Quentin, Wilm. (2015). A roadmap for comparing readmission policies with application to Denmark, England, Germany and the United States. Dalam http://googleweblight.com/?lite_url=http://www.sciencedirect.com/s cience/article/pii/S0168851014003431\&ei=1QhWN591\&lc=idID\&s $=1 \& \mathrm{~m}=676 \& \mathrm{ts}=1449719603 \& \mathrm{sig}=\mathrm{ALL} 1 \mathrm{Aj} 4 \mathrm{o} 2 \mathrm{vIj} 7 \mathrm{qvbzETKF}$ qQHDWIpoYM-5w, diakses pada 5 Mei 2017.

Or, Zeynep and Häkkinen, Unto (2011). DRGs and quality: For better or worse? In R. Busse, A. Geissler, W. Quentin, \& M. Wiley (Eds.), Diagnosis-Related Groups in Europe : Moving towards transparency, efficiency and quality in hospitals (pp. 115-129). Maidenhead, Berkshire, England: Open University Press.

OSLA (2014). Pushed Out of Hospital, Abandoned at Home: After Twenty Years of Budget Cuts, Ontario's Health System is Failing Patients.
Dalam https://www.osla.on.ca/uploads/Pushed\%20Out $\% 20$ of $\% 20$ Hospital \%20FINAL_February\%202014.pdf, diakses pada 25 April 2017

UnitedHealthcare, (2017). Hospital Readmissions. Dalam https://www.unitedhealthcareonline.com/ccmcontent/ProviderII/UH C/en-

US/Assets/ProviderStaticFiles/ProviderStaticFilesPdf/Tools\%20and
\%20Resources/Policies\%20and\%20Protocols/Medical\%20Policies/ Medical\%20Policies/Hospital_Readmissions.pdf, diakses pada 12 Juli 201 